1 Williams D, Rolles CJ, White JE. Lyme disease in a Hampshire child-medical curiosity or beginning of an epidemic? Br Med f 1986;292:1560-1.

2 Pachner AR, Steere AC. The triad of neurological manifestations of Lyme disease: meningitis, cranial neuritis and radiculoneuritis. Neurology $(N Y)$ 1985;35:47-53.

3 Pachner AR, Steere AC. Neurological findings of Lyme disease. Yale f Biol Med 1984;57:481-3.

4 Steere AC, Pachner AR, Malawista SE. Neurological abnormalities of Lyme disease: successful treatment with high-dose intravenous penicillin. Ann Intern Med 1983;99:767-72.

5 Steere AC, Grodzicki RL, Kornblatt AN, et al. The spirochetal etiology of Lyme disease. N Engl Med 1983;308:733-40.

(Accepted 4 November 1986)

Wessex Neurological Centre and Department of Dermatology, Southampton General Hospital, Southampton SO9 4XY

D E BATEMAN, MD, MRCP, senior registrar

J E WHITE, MD, FRCP, consultant dermatologist

G ELRINGTON, MB, MRCP, registrar

N F LAWTON, MD, FRCP, consultant neurologist

Department of Dermatology, Charing Cross Hospital, London W6 8RF

M F MUHLEMANN, MB, MRCP, senior registrar

Department of Neurological Sciences, St Bartholomew's Hospital, London EC1A 7BE

R J GREENWOOD, MD, MRCP, consultant neurologist

Correspondence to: Dr Bateman.

\section{Effect of carbonic anhydrase inhibitors on glomerular filtration rate in diabetic nephropathy}

Proliferative retinopathy and secondary glaucoma are much more common in insulin dependent diabetics with diabetic nephropathy than in those without. Carbonic anhydrase inhibitors are widely used to treat glaucoma because they reduce the rate of formation of aqueous humour. Recently we observed large reductions in glomerular filtration rate during treatment with carbonic anhydrase inhibitors in insulin dependent diabetics with nephropathy and glaucoma. We wish to call attention to this side effect, which seems to have gone unnoticed in the past, perhaps because of its reversible nature. ${ }^{1}$

\section{Case reports}

CASE 1

A 31 year old man with insulin dependent diabetes complicated with nephropathy, arterial hypertension, proliferative retinopathy, and glaucoma secondary to iridocyclitis was admitted to hospital because of malaise, vomiting, and poor metabolic control. Ten days before admission he had started treatment with a carbonic anhydrase inhibitor, dichlorphenamide, $50 \mathrm{mg}$ three times daily.

On admission he had a blood glucose concentration of $20.4 \mathrm{mmol} / \mathrm{l}$; bicarbonate concentration of $15 \mathrm{mmol} /$, no ketonuria, and a serum creatinine concentration of $357 \mu \mathrm{mol} / \mathrm{l}$. His metabolic control and dehydration were corrected, but the serum creatinine concentration dropped to only $314 \mu \mathrm{mol} /$ and the glomerular filtration rate was severely reduced $\left(10 \mathrm{ml} / \mathrm{min} .1 .73 \mathrm{~m}^{2}\right.$ eight days after admission) (table). Two months before admission his serum creatinine concentration had been $223 \mu \mathrm{mol} / \mathrm{l}$ and the glomerular filtration rate measured with a technique using edetic acid labelled with chromium-51 was $23 \mathrm{ml} / \mathrm{min} .1 .73 \mathrm{~m}^{2} .^{2}$ As he did not have a urinary tract infection and the antihypertensive treatment (prazosin $7.5 \mathrm{mg} /$ day, metoprolol $150 \mathrm{mg} /$ day, and frusemide $250 \mathrm{mg} /$ day) had remained unchanged we suspected that the carbonic anhydrase inhibitor had induced the acute deterioration in kidney function. This treatment was stopped, and his clinical condition improved: five days later serum creatinine concentration had fallen to $230 \mu \mathrm{mol} / 1$ and three months later glomerular filtration rate was again $23 \mathrm{ml} / \mathrm{min} .1 \cdot 73 \mathrm{~m}^{2}$.

CASE 2

A 41 year old man with insulin dependent diabetes suffering from nephropathy, arterial hypertension, proliferative retinopathy, and haemorrhagic glaucoma was admitted to hospital because of tiredness and poor metabolic control; he had a blood glucose concentration of $17 \cdot 1 \mathrm{mmol} / 1$ and no ketonuria. Two months before admission he had undergone vitrectomy, but glaucoma had developed and acetazolamide $250 \mathrm{mg}$ twice a day had been started. The table shows his kidney function before, during, and after acetazolamide treatment.

CASE 3

A 41 year old woman with insulin dependent diabetes suffering from nephropathy, arterial hypertension, and proliferative retinopathy visited the outpatient clinic for a routine check up. One week before she had developed iridocyclitis with secondary glaucoma and treatment with acetazolamide $250 \mathrm{mg}$ twice a day had been started. We observed a slight rise in the serum creatinine concentration, and so the glomerular filtration rate was determined using ${ }^{5} \mathrm{Cr}$-edetic acid. ${ }^{2}$ Three weeks later the intraocular pressure was normal, acetazolamide treatment stopped, and kidney function improved (table).

\section{Comment}

Intravenous injection of acetazolamide induces a slight (10-15\%) reduction in the glomerular filtration rate in normal men. ${ }^{3}$ Micropuncture studies in rats have shown reduced proximal tubular absorption of fluid and electrolytes, suggesting that activation of the tubuloglomerular feedback mechanism is the main cause of the reduced glomerular filtration rate during administration of acetazolamide. ${ }^{4}$

Our cases show that carbonic anhydrase inhibitors may considerably reduce the glomerular filtration rate in diabetic nephropathy. The reduction in kidney function brought one patient close to the limit for starting dialysis treatment. The reversible decline in kidney function was not due to urinary tract infection, diabetic ketoacidosis, or arterial hypotension. All three patients received antihypertensive treatment, which remained unchanged during the observation period. This side effect of carbonic anhydrase inhibition may have escaped attention in the past because of its reversible nature or because serum creatinine concentration, which is a rather insensitive index, has been used to measure glomerular filtration rate, or both. ${ }^{5}$

1 Weiner IM, Mudge GH. Diuretics and other agents employed in the mobilization of edema fluid. In: Gilman AG, Goodman LS, Rall TW, Murad F, eds. Goodman and Gilman's the pharmacological basis of therapeutics. 7th ed. New York: Macmillan Publishing Company, 1985:887-907.

2 Bröchner-Mortensen J, Giese J, Rossing N. Renal inulin clearance versus total plasma clearance of ${ }^{51}$ Cr-EDTA. Scand I Clin Lab Invest 1969;23:301-5.

3 Puschett JB, Goldberg $M$. The relationship between the renal handling of phosphate and bicarbonate in man. 7 Lab Clin Med 1969:73:956-69.

4 Persson AEG, Wright FS. Evidence for feedback mediated reduction of glomerular filtration rate during infusion of acetazolamide. Acta Physiol Scand 1982;114:1-7.

5 Shemesh $\mathrm{O}$, Golbetz H, Kriss JP, Myers BD. Limitations of creatinine as a filtration marker in glomerulopathic patients. Kidney Int 1985;28:830-8.

(Accepted 6 October 1986)

Hvidöre Hospital, Klampenborg, Denmark

P SKØTT, MD, registrar

E HOMMEL, MD, registrar

$S$ ARNOLD-LARSEN, MD, registrar

H-H PARVING, MD, chief physician

Correspondence to: Dr Parving.

Kidney function, arterial blood pressure, and blood glucose concentration before, during, and after treatment with carbonic anhydrase inhibitors in insulin dependent diabetics with nephropathy and secondary glaucoma

\begin{tabular}{|c|c|c|c|c|c|c|c|c|c|}
\hline \multirow[t]{2}{*}{ 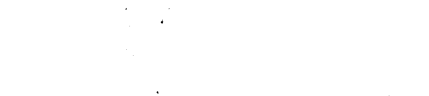 } & \multicolumn{3}{|c|}{ Case 1} & \multicolumn{3}{|c|}{ Case 2} & \multicolumn{3}{|c|}{ Case 3} \\
\hline & Before ${ }^{\star}$ & During & After $\star$ & Before* & During & After $\star$ & Before ${ }^{\star}$ & During & After ${ }^{\star}$ \\
\hline $\begin{array}{l}\text { Glomerular filtration rate }\left(\mathrm{ml} / \mathrm{min} .1 .73 \mathrm{~m}^{2}\right) \\
\text { Serum creatinine }(\mu \mathrm{mol} / \mathrm{l}) \\
\text { Blood pressure }(\mathrm{mm} \mathrm{Hg}) \\
\text { Blood glucose }(\mathrm{mmol} / \mathrm{l})\end{array}$ & $\begin{array}{l}23 \\
223 \\
147 / 93 \\
8 \cdot 1\end{array}$ & $\begin{array}{l}10 \\
314 \\
155 / 90 \\
11 \cdot 8\end{array}$ & $\begin{array}{l}23 \\
230 \\
150 / 90 \\
11 \cdot 6\end{array}$ & $\begin{array}{c}93 \\
146 / 96 \\
19 \cdot 5\end{array}$ & $\begin{array}{l}56 \\
119 \\
135 / 85 \\
7 \cdot 0\end{array}$ & $\begin{array}{c}79 \\
95 \\
150 / 86 \\
10 \cdot 5\end{array}$ & $\begin{array}{l}48 \\
135 \\
122 / 90 \\
3 \cdot 7\end{array}$ & $\begin{array}{c}31 \\
151 \\
107 / 86 \\
3 \cdot 2\end{array}$ & $\begin{array}{c}51 \\
138 \\
111 / 75 \\
8 \cdot 4\end{array}$ \\
\hline
\end{tabular}

${ }^{\star}$ Measurements made within four months before and four months after treatment with a carbonic anhydrase inhibitor. 